\title{
Liability for Intentional Crime as Consequence of Traffic Offenses - Comparative Considerations
}

\author{
Renata Pawlik
}

Abstract: The subject of the paper is an analysis of the issue of criminal responsibility for participation in illegal car races and the possibility of assigning it to drivers deliberately causing the risk of death of another traffic participant. The author, using the example of events taking place in Germany, Slovakia and Poland, indicates the need to prosecute their participants who caused death of another person taking part in the traffic for intentional homicide or murder. The paper examines the issue of responsibility for causing common danger in traffic and presents arguments supporting the idea of assigning such responsibility to people who show bravado in road traffic and disregard danger they cause for life and health of other road users.

Key Words: Criminal Law; Traffic Offense; Intent; Negligence; Attribution of Result; Common Danger; Illegal Car Racing; Disregard for Legal Good; Penal Code; Germany; Slovakia; Poland.

\section{Introduction}

Road safety in Europe has improved significantly in recent years (the European Union's road infrastructure is among the safest in the world). Nevertheless, the death toll and the number of injured are still far too high. Consequently, the European Union has adopted the Vision Zero and Safe System approach created to eliminate fatalities and serious injuries on the European roads. The European Union works closely with the Member States on road safety. It wishes to use national initiatives to set targets and to take into account all the factors that play a role in road accidents (infrastructure, vehicle safety, driver behaviour, emergency response). To this end, the European Union adopts legislation, supports public information campaigns, enables the Member States and other road safety actors to share their experiences and provides funding. ${ }^{1}$

1 See Road Safety. In: Komisja Europejska [online]. 2019-03-13 [cit. 2020-07-24]. Available at: https://ec.europa.eu/commission/news/road-safety-2019-mar-13_pl; and Ramy poli- 
The considerations presented in this paper are based on the events that took place in three Central European countries - Germany, Slovakia and Poland in the last few years and aroused lively interest among criminal law specialists, which crossed the borders of these countries. All these events had a common denominator - as a result of the irresponsible and reckless behaviours of drivers participating in illegal street races caused death of unfortunate witnesses of these events - other participants of the traffic those obeyed its rules.

\section{Factual basis for considerations}

The first and best known of these events took place over four years ago in Germany. As the only one, it has been finally resolved by the judgement brought by the $4^{\text {th }}$ Criminal Senate of the German Supreme Court on June $18,2020 .^{2}$

Two drivers, H. and N., drove the Kurfürstendamm in Berlin at around 0.30 a.m. on February 1, 2016, with K. as a passenger in the N.'s vehicle. Both drivers who had come to a stop next to each other in front of a red traffic light agreed to carry out a race to the next red traffic light. They first drove two sections of the street over a distance of about 300 meters each, which N., thanks to the power of his car's engine, clearly won, and then decided to take part in a spontaneous car race at a distance of more than 1.5 kilometres. N. overtook H., then continued to increase the distance to his opponent and was the first to drive in the left lane at a speed of 90 to $100 \mathrm{~km} / \mathrm{h}$ at the Kaiser Wilhelm Memorial Church, making the transition from the Kurfürstendamm in the Tauentzienstrasse. The speed of $\mathrm{H}$., driving parallel in the right lane, was already 120 to $130 \mathrm{~km} / \mathrm{h}$.

Shortly before the exit of the curve, both drivers spotted and ignored the red light on the traffic light system for their direction of travel and drove into the Tauentzienstrasse. After the corner exiting, both men noticed that the traffic light system at the intersection of the Tauentzienstrasse with the Nürnberger Strasse, in a straight line ahead of them, emitted red light for their direction of travel. In this situation, H. who was not wearing his seat belt and was expecting acquaintances at the square

tyki bezpieczeństwa ruchu drogowego UE na lata 2021 - 2030 - Kolejne kroki w kierunku realizacji „wizji zero“" [2019-06-19]. SWD (2019) 283 final.

2 See Judgement of the Bundesgerichtshof Ref. No. 4 StR 482/19 [2020-06-18]; and Judgement of the Bundesgerichtshof Ref. No. 4 StR 399/17 [2018-03-01]. 
behind the intersection become aware that he had to accelerate as much as possible in order to win the race. He was aware that, despite the night time, there was still car traffic and that he would only be able to perceive vehicles crossing from the right of the Nürnberger Strasse. He calculated the potential impact with regard to the modern safety equipment of the vehicles controlled by him and his rival N., and in the case of an accident which he recognized as possible, he was certain that his and his rival's vehicle will collide with the much less protected side areas of other cars, suffering only minor injuries.

Although N. was aware that timely braking was still possible at this moment, he decided, because of $\mathrm{H}$. was catching up and driving much faster, to continue the race under these conditions, in order to win it, and he pushed the accelerator again. Both drivers entered the intersection almost simultaneously, while the traffic light system continued to emit red light. In the intersection, H.'s car collided at speed of at least $160 \mathrm{~km} / \mathrm{h}$ with the victim W.'s vehicle which came from the Nürnberger Strasse from the right side of both race participants in the direction of the intersection, with a green traffic light signal. As a result of the impact, the victim's car was thrown in the air and completely destroyed. Its driver suffered serious injuries and died on site. The passenger in the N.'s vehicle was also seriously injured. ${ }^{3}$

As a result of the preparatory proceedings, both drivers were charged with murder committed in cooperation as well as deliberately causing serious injuries to the passenger involved in the accident, and deliberately bringing a common danger in road traffic. This charge was found to be justified in relation to both defendants by the National Court in Berlin which, in the judgement of February 27, 2017, sentenced each of the perpetrators to life imprisonment.

As a result of the appeals of both defendants, the German Supreme Court, in its judgement of March 1, 2018, repealed the judgement under appeal in its entirety and referred the case to the National Court in Berlin for reconsideration, pointing out significant doubts as to the attribution of cooperation of both perpetrators and, in particular, the existence of intent on their side. ${ }^{4}$ The court meriti, following the contents of this deci-

3 See Judgement of the Bundesgerichtshof Ref. No. 4 StR 482/19 [2020-06-18]; and Judgement of the Bundesgerichtshof Ref. No. 4 StR 399/17 [2018-03-01].

4 See Judgement of the Bundesgerichtshof Ref. No. 4 StR 399/17 [2018-03-01]. 
sion, issued another judgement on March 26, 2019, in which it again convicted the perpetrators based on all the previously presented charges.

The consequence of the following appeals was the decision of the German Supreme Court of June 18, 2020, in which the $4^{\text {th }}$ Criminal Senate again repelled the judgement in the part concerning the accused $\mathrm{N}$. and changed the content of the judgement in the part concerning $\mathrm{H}$., whom it found guilty of murder and of deliberately bringing common danger in traffic, however, it attributed the injury to the passenger of the other vehicle as negligent. The Berlin National Court will, therefore, re-examine N.'s case in the future, but the decision about H. has become final. ${ }^{5}$

Another incident happened more than two years later. On September 30, 2018, there was a tragic accident near Dolný Kubín in Slovakia, in which a 57-year-old resident of Oravský Podzámok was killed. The perpetrators of the tragedy were three Poles. ${ }^{6}$

According to the findings of the Slovak police, in the vicinity of Dolný Kubín in Slovakia, drivers of the Ferrari 458 Spider, Mercedes-AMG C43 Coupe and Porsche Cayenne organized an illegal race leading through the mountains, on windy roads No. 78 and 59. Ignoring signs and lines on the asphalt, they tried to avoid other cars. However, two of them miscalculated and did not manage to return to their lane after one of the risky manoeuvres. K., the driver of the Mercedes, had more luck, overtaking first. He managed to finish the manoeuvre and to return to his lane. Two more men were just behind him. The first was S., the driver of the Ferrari, with a Porsche just behind him. At some point, a properly driven Škoda Fabia appeared in front of them. The 27-year-old S. managed to pull into the right lane and to avoid a head-on collision. At this point, the speeding Porsche Cayenne hit the rear of the Ferrari first, and then the 42-year-old driver L. tried to take off to the side of the road. The 57-year-old 0., the Škoda driver, wanting to avoid an accident, did exactly the same. In the head-on collision he was seriously injured and died on the way to hospital. His 50-year-old wife and 21-year-old son survived, but were badly injured.

5 See Judgement of the Bundesgerichtshof Ref. No. 4 StR 482/19 [2020-06-18].

6 See Polacy w porsche, ferrari i mercedesie spowodowali koszmarny wypadek na Słowacji [WIDEO]. In: Żywiec Nasze Miasto [online]. 2018-10-01 [cit. 2020-07-24]. Available at: https://zywiec.naszemiasto.pl/polacy-w-porsche-ferrari-i-mercedesie-spowodowalikoszmarny/ar/c16-4823017. 
Immediately after committing the act, all three Poles were arrested on charges of deliberately causing general danger in traffic. After only a few days, the driver of the Mercedes K. was released from arrest, and in the spring of the following year also $\mathrm{S}$. has been released. A bail was imposed on both of them, and electronic supervision was also applied to the former. However, the Slovak public prosecutor's office decided not to charge any of them with intentional murder. ${ }^{7}$

The third and last of the events which inspired this analysis took place in Poland on October 27, 2018. The 25-year-old 0., driver of a Seat, and the 21-year-old L., driving a Volkswagen, participated in an illegal car race along the streets of Jelenia Góra in Poland. ${ }^{8}$ Young men drove cars at speeds of 160 to $180 \mathrm{~km} / \mathrm{h}$. According to the local prosecutor's office, they passed three intersections and six pedestrian crossings, exceeding the speed limit by over $100 \mathrm{~km} / \mathrm{h}$. As they approached the marked and illuminated pedestrian crossing, there were two people on it - a 47-yearold woman and a 57-year-old man, crossing the road correctly.

The driver of a Seat, O., overtaking the second participant of the race, drove into the crossing and hit both pedestrians, killing them instantly. Men were accused by the prosecutor that, acting jointly and in concert, participating in an illegal car race, foreseeing the possibility of killing the victims and agreeing to it, they had committed murder with a possible intent. Both were also accused of intentional bringing the immediate danger of a crash in land traffic.

Investigators found out that before the accident both drivers participated in meetings organized by an informal group of car enthusiasts in Jelenia Góra. In the cars they raced, the experts found engine modifications that significantly increased the power. The danger was all the more serious as the suspension components and the brakes were not modified in any way.

\footnotetext{
7 See MAREŠOVÁ, I. Poliak, ktorý bol účastníkom tragickej naháňačky na Orave, sa postavil pred súd. In: Noviny.sk [online]. 2019-06-06 [cit. 2020-07-24]. Available at: https://www. noviny.sk/krimi/446838-poliak-ktory-bol-ucastnikom-tragickej-nahanacky-na-orave-sapostavil-pred-sud; and Pirátska jazda Poliakov: Súd rozhodol o poslednom z nich, ktorý má na tragédii najväčší podiel viny. In: Topky.sk [online]. 2019-06-07 [cit. 2020-07-24]. Available at: https://www.topky.sk/cl/100370/1800401/Piratska-jazda-Poliakov--Sudrozhodol-o-poslednom-z-nich--ktory-ma-na-tragedii-najvacsi-podiel-viny.

8 See Ścigali się ulicami miasta. Zginęły dwie osoby. Jest akt oskarżenia. In: Lwówecki.info [online]. 2019-10-16 [cit. 2020-07-24]. Available at: https://lwowecki.info/scigali-sieulicami-miasta-zginely-dwie-osoby-jest-akt-oskarzenia/.
} 
In the case of both perpetrators, the prosecutor requested temporary arrest. The court upheld the request with regard to the direct participant in the pedestrian collision, but rejected it in relation to L. - the driver of a Volkswagen, which formally does not repeal, but seriously puts in doubt the effectiveness of charging him with intentional murder.

\section{Potential grounds for criminal responsibility}

Already a preliminary analysis of the decisions made in the course of the proceedings indicates the issue that is the main subject of this argument. The tendency emerging among the law enforcement agencies to treat as deliberate behaviour of those perpetrators who, by showing blatant disregard for the life and health of other road users, commit reckless and extremely irresponsible behaviour, ostentatiously rejecting the applicable precautionary rules, encounters reluctance on the part of the courts, especially those with a natural tendency towards a certain conservatism - the highest judicial organs. ${ }^{9}$ The reason for this is the belief established in the past decades that road crimes are a consequence of recklessness, irresponsibility and frequent overestimation of one's own skills, but are not related to the intention of the perpetrator to attack the legal good. 10

9 See Decision of the Supreme Court of the Republic of Poland Ref. No. V KZP 2/74 [1975-0228]. OSNKW 1975, no. 3-4, item 33; OLSZEWSKI, M. Ochrona bezpieczeństwa drogowego w nowym kodeksie karnym. Palestra. 1970, nr 4, p. 38. ISSN 0031-0344; G. Bogdan in ZOLL, A. ed. Kodeks karny: Część szczególna: Komentarz: Tom II: Komentarz do art. 117 277 k.k. 2. wyd. Warszawa: Zakamycze, 2006. 1438 p. ISBN 83-7444-252-2; BUCHAŁA, K. Niektóre problemy wykładni znamion przestępstw przeciwko bezpieczeństwu w komunikacji. Prokuratura i Prawo. 1998, nr 11-12, pp. 7-17. ISSN 1233-2577; and BUCHAŁA, K. Niektóre zagadnienia nowelizacji prawa karnego. Państwo i Prawo. 1996, vol. 51, nr 3, pp. 3-12. ISSN 0031-0980.

${ }^{10}$ See STEFAŃSKI, R. A. Przestępstwa przeciwko bezpieczeństwu powszechnemu i w komunikacji: Rozdział XX i XXI Kodeksu karnego: Komentarz. 1. wyd. Warszawa: C. H. Beck, 2000, pp. 170-172. ISBN 83-7110-239-9; SPOTOWSKI, A. Funkcja niebezpieczeństwa w prawie karnym. 1. wyd. Warszawa: Państwowe Wydawnictwo Naukowe, 1990, p. 86. ISBN 83-0109521-0; PRUSAK, F. and G. WOŚKO. Śmiertelne wypadki drogowe: Aspekty procesowe i medyczne. In: K. SŁAWIK, ed. Współczesna przestępczość: Problemy prawnokarne, kryminalistyczne i kryminologiczne. 1. wyd. Szczecin: JotA, 1996, p. 161. ISBN 83-901965-4-9; KOCHANOWSKI, J. Zagadnienia przestępstw drogowych i przeciwko bezpieczeństwu w komunikacji. 1. wyd. Warszawa: Naczelna Rada Adwokacka, 1990, p. 11; Judgement of the Supreme Court of the Republic of Poland Ref. No. V KKN 303/97 [1998-11-04]. OSNKW 1998, no. 11-12, item 50, with gloss of K. J. Pawelec, Mon. Praw. 1999, no. 5, pp. 43-44. See also ZABŁOCKI, S. Przegląd orzecznictwa Sądu Najwyższego - Izba Karna. Palestra. 1999, nr 1-2, pp. 146-147. ISSN 0031-0344; Judgement of the Supreme Court of the Republic of Poland Ref. No. III KKN 231/98 [2000-03-08]. OSNKW 2000, no. 5-6, item 45, with approv- 
The main argument in this case is the symmetry of the threat; traffic incidents naturally endanger the life, health and property of the perpetrator himself/herself, so how could the person responsible for committing them act on purpose? Experience shows, however, that such cases are possible, especially since the cars used, for example, in illegal street races, are more modern and, therefore, usually also safer than the vehicles of most road users. This occasionally leads to the conscious behaviour of participants of illegal rallies, choosing in crisis situations a collision with an older and less protected car of another driver, instead of hitting a building, trunk or other dangerous part of the roadside.

When looking at the legal tools being at the disposal of the judicial authorities of all three countries, it is easy to notice that the similarities clearly outnumber the differences. Within the German, ${ }^{11}$ Slovak $^{12}$ and

ing glosses of J. Giezek, PiP 2001, no. 6, pp. 109-114; A. Górski, OSP 2001, no. 6, pp. 317319; J. Majewski, OSP 2001, no. 10, pp. 491-493; and J. M. Iwaniec, Prokurator 2001, no. 4, pp. 68-73; BOCKELMANN, P. Der Schuldgehalt des menschlichen Versagens im Straßenverkehr. Deutsches Autorecht. 1964, p. 288 and following. ISSN 0012-1231; BÖHMER, E. Der Vertrauensgrundsatz im Straßenverkehr in der neueren Rechtsprechung. Monatsschrift für deutsches Recht. 1964, p. 100 and following. ISSN 0340-1812; and BÖHMER, E. Der Vertrauensgrundsatz im Straßenverkehr in der Rechtsprechung. Juristische Rundschau. 1967, p. 291 and following. ISSN 0022-6920.

${ }^{11}$ See $\S 223$ of the German Strafgesetzbuch: (1) Who physically abuses or harms another person's health is punished with imprisonment of up to five years or a fine; (2) The attempt is punishable. See also § 224 of the German Strafgesetzbuch: (1) Who commits the assault 1. by administration of poison or other harmful substances, 2 . with a weapon or other dangerous tool, 3. through an insidious robbery, 4. jointly with another party, or 5. with a life-threatening treatment, is punished with a prison sentence of six months to ten years, in less severe cases with a prison sentence of three months to five years; (2) The attempt is punishable. See also $\S 229$ of the German Strafgesetzbuch: Who causes another person's bodily harm through negligence will be punished with imprisonment of up to three years or a fine. See Strafgesetzbuch [1998-11-13]. BGBl. I S. 3322, last changed by law on July 10, 2020 (BGBl. I S. 1648).

${ }^{12}$ See $§ 155$ of the Slovak Trestný zákon: (1) Any person who intentionally causes grievous bodily harm to another person shall be liable to a term of imprisonment of four to ten years; (2) The offender shall be liable to a term of imprisonment of five to twelve years if he/she commits the offence referred to in $\S 1$ a) acting in a more serious manner, b) against a protected person, or c) by reason of specific motivation; (3) The offender shall be liable to a term of imprisonment of ten to fifteen years if he/she commits the offence referred to in $\S 1$ a) as a member of a dangerous group, or b) under a crisis situation. See also § 156 of the Slovak Trestný zákon: (1) Any person who intentionally causes bodily harm to another person shall be liable to a term of imprisonment of between four months and two years; (2) The offender shall be liable to a term of imprisonment of one to three years if he/she commits the offence referred to in $\S 1$ a) against a protected person, or b) by reason of specific motivation; (3) The offender shall be liable to a term of imprisonment of two to five years if he/she commits the offence referred to in $\S 1$ 
Polish ${ }^{13}$ criminal law orders, one can indicate provisions relating to inflicting injuries of various degrees of severity to the victim, which may be caused both intentionally and unintentionally - which leads to a clearly milder punishment. Within the German, ${ }^{14}$ Slovak $^{15}$ and Polish ${ }^{16}$ legal or-

\begin{abstract}
a) acting in a more serious manner, or b) under a crisis situation. See Act No. 300/2005 Coll. of 20 May 2005 the Criminal Code [The Criminal Code of the Slovak Republic].

${ }^{13}$ See Article 177 of the Polish Kodeks karny: $§ 1$. Whoever by violating, even unintentionally, the safety rules of land, water or air movement causes unintentionally an accident in which another person suffered bodily injuries specified in the Article $157 \S 1$, shall be punished by imprisonment for up to three years; $\S 2$. If the consequence of an accident is a death of another person or a heavy damage to his/her health, the perpetrator shall be punished by imprisonment from six months to eight years; $\S 3$. If the victim is the nearest person, the prosecution of the person referred to in $\S 1$ shall be conducted at the request of the victim. See Ustawa z dnia 6 czerwca 1997 r. - Kodeks karny. Dziennik Ustaw 2019, item 1950, 2128; and Dziennik Ustaw 2020, item 568, 875, 1086.
\end{abstract}

${ }^{14}$ See $\S 315$ c of the German Strafgesetzbuch: (1) Whoever on the road 1. is driving a vehicle, though a) as a result of drinking alcoholic beverages or other intoxicating substances, or b) due to mental or physical deficiencies is unable to drive the vehicle safely, or 2. grossly contrary to traffic and reckless a) ignores the right of way, b) incorrectly overhauls or otherwise driving incorrectly when overtaking, c) drives wrong at pedestrian crossings, d) drives too fast in confusing places, at intersections, road junctions or level crossings, e) does not adhere to the right side of the lane in confusing places, f) on highways or motorways, reversing or moving against the right direction or trying to do so, g) does not mark vehicles that are at a standstill or have come to rest at a sufficient distance, although this is necessary to ensure traffic, and thereby endangers the life or health of another person or alien objects of significant value, is punished with imprisonment for up to five years or with a fine; (2) In the cases of section 1 point 1 , the attempt is punishable; (3) Who in the cases of $\S 11$. causes the danger by negligence, or 2 . acts negligently and causes the danger negligently, is punished with imprisonment of up to two years or a fine. See Strafgesetzbuch [1998-11-13]. BGBl. I S. 3322, last changed by law on July 10, 2020 (BGBl. I S. 1648).

${ }^{15}$ See $\S 284$ of the Slovak Trestný zákon: (1) Who intentionally a) puts people at risk of death or serious injury or property loss to the detriment of large-scale damage by causing a fire or flood, or breakdown or accident of a means of public transport, or the harmful effect of explosives, gas, electricity, radioactivity or other similar dangerous substances or forces, or commits other similar dangerous conduct (general danger), or b) the general danger increases or makes it more difficult to avert or to mitigate it, shall be punishable by a term of imprisonment of four to ten years; (2) The offender shall be punished by imprisonment for ten to fifteen years if he/she commits the act referred to in $\S 1$ a) in a more serious course of action, b) on the protected person, c) for a specific purpose, or d) to frustrate or to impede another's exercise of his or her fundamental rights and freedoms; (3) The offender shall be punished by imprisonment for fifteen to twenty years if he/she commits the act referred to in $\S 1$ a) causing serious injury or death, or b) as a member of a dangerous group; (4) An offender shall be punished by imprisonment for a term of twenty years to twenty-five years or a sentence of life imprisonment if he/she commits an act referred to in $\S 1$ a) and thereby causes serious injury or death to several persons, or b) in a crisis situation. See also § 285 of the Slovak Trestný zákon: (1) Whoev- 
ders, we will also come across some provisions relating to criminal liability for creating a general threat to human health, sometimes also to property. Such behaviour can also be intentional or unintentional. In the first case, the more severe punishment is determined by the unintentional effect for the protected good. In the case of the three analysed legislations, these provisions, relating to traffic situations, are present in criminal codifications, sometimes by the way of separate regulations and sometimes by recognizing communication behaviour as one of the forms that an offense may adopt.

In the criminal legislations of Germany, ${ }^{17}$ Slovakia ${ }^{18}$ and Poland, ${ }^{19}$ we will also come across provisions introducing a criminal liability for be-

er negligently causes or increases a general danger, or makes it more difficult to avert or to mitigate it, shall be punished by imprisonment for up to one year; (2) An offender shall be punished by imprisonment for a term of six months to three years if he/she commits the act referred to in $\S 1$ in a more serious manner; (3) An offender shall be punished by imprisonment for two to five years if he/she commits the act referred to in $\S 1$ and causes a) significant damage, or b) serious injury or death; (4) An offender shall be punished by imprisonment for four to ten years if he/she commits the act referred to in $\S 1$ and causes serious harm to the health of several persons or the death of several persons. See Act No. 300/2005 Coll. of 20 May 2005 the Criminal Code [The Criminal Code of the Slovak Republic].

${ }^{16}$ See Article 173 of the Polish Kodeks karny: $\S 1$. Who commits a catastrophe in the presence of people in the land, water or air, affecting the life or health of many persons or intending to a large extent, shall be punished by imprisonment from one to ten years; $\S 2$. If the perpetrator acts negligently, shall be punished by imprisonment for a term of between three months and five years; $\S 3$. If the consequence of the act specified in $\S 1$ is human death or serious damage to the health of many people, the perpetrator shall be punished by imprisonment for a term of between two and twelve years; $\S 4$. If the consequence of the act specified in $\S 2$ is human death or serious damage to the health of many people, the perpetrator shall be punished by imprisonment from six months to eight years. See also Article 174 of the Polish Kodeks karny: $§ 1$. Whoever brings the immediate danger of a disaster in land, water or air traffic, shall be punished by imprisonment from six months to eight years; $\S 2$. If the perpetrator acts negligently, he/she shall be punished by imprisonment for up to three years. See Ustawa z dnia 6 czerwca $1997 \mathrm{r}$. - Kodeks karny. Dziennik Ustaw 2019, item 1950, 2128; and Dziennik Ustaw 2020, item 568, $875,1086$.

${ }^{17}$ See $\S 211$ of the German Strafgesetzbuch: (1) The murderer is punished with life imprisonment; (2) Murderer is who out of a lust for murder, for the satisfaction of the sexual instinct, out of greed or otherwise for low motives, insidious or cruel or by means dangerous to the public or to enable or to cover up another crime kills a human being. See also $\S 212$ of the German Strafgesetzbuch: (1) Anyone who kills a person without being a murderer will be punished with a prison sentence of no less than five years; (2) In particularly severe cases, a life sentence can be recognized. See Strafgesetzbuch [1998-1113]. BGBl. I S. 3322, last changed by law on July 10, 2020 (BGBl. I S. 1648). 
haviour that directly affects human life. The homicide may be result of a careless behaviour of a road user, although in the cases described in this paper, it would be advisable to consider separate (and more severe) cases of homicide as a consequence of the common danger brought earlier by the perpetrator.

Finally, the last and most radical form of describing the perpetrator's behaviour is attribution to him/her responsibility for intentional murder. Such liability may take a special form, leading to the necessity to impose drastically severe punishment when the victim's death was caused in a special way or the perpetrator was driven by a specific motivation.

Bolder use of the construction of intentional offenses is conditioned by the fulfilment of one more requirement, namely the existence of provisions in the general part of the code, allowing the use of a broad framework of assigning intention. We can confirm their existence in the case of each of the three discussed legislations.

${ }^{18}$ See $\S 145$ of the Slovak Trestný zákon: (1) Whoever intentionally kills another shall be punished by imprisonment for fifteen to twenty years; (2) The offender shall be punished by imprisonment for a term of twenty years to twenty-five years or by a sentence of life imprisonment if he/she commits an act referred to in $\S 1$ a) on two persons, b) of more serious conduct, c) on the protected person, d) for a specific purpose, or e) with the intent of obtaining a pecuniary benefit; (3) An offender shall be punished by imprisonment for twenty-five years or a sentence of life imprisonment if he/she commits an act referred to in $\S 1$ a) and has already been convicted of such an act or of an offense of assassination, b) in a dangerous group, or c) in a crisis situation. See Act No. 300/2005 Coll. of 20 May 2005 the Criminal Code [The Criminal Code of the Slovak Republic].

${ }^{19}$ See Article 148 of the Polish Kodeks karny: $\S 1$. Whoever kills a man shall be punished by imprisonment for a period not less than eight years, a loss of freedom for twentyfive years or the life imprisonment; $\S 2$. Who kills a man 1) with particular cruelty, 2) in connection with the hostage-taking, rape or robbery, 3) as a result of a motivation that deserves particular condemnation, 4) with the use of explosive materials, shall be punished by imprisonment for a period of time not less than twelve years, a loss of freedom for twenty-five years or the life imprisonment; $\S 3$. The penalty specified in $\S 2$ shall be imposed on anyone who kills more than one person with one act or has previously been legally convicted of homicide and the perpetrator of the murder of a public official committed during or in connection with the performance of his/her official duties related to the protection of human safety or the protection of public safety or order; $\S 4$. Who kills a person in a state of strong agitation justified by the circumstances, shall be punished by imprisonment from one to ten years. See Ustawa z dnia 6 czerwca 1997 r. - Kodeks karny. Dziennik Ustaw 2019, item 1950, 2128; and Dziennik Ustaw 2020, item 568, 875, 1086. 


\section{Intent and negligence in traffic offenses}

Regulation of $\S 15$ of the German Criminal $\operatorname{Code}^{20}$ does not contain a definition of intentional and unintentional actions, but determines that as a rule only deliberate action is punishable. The generally accepted definition is: "Intent is knowledge and willingness to realize the goal", which means that the resolution is a psychic phenomenon that consists of two components - knowledge (intellectual element) and will (voluntative element). ${ }^{21}$

The knowledge and will components only have to relate to the realization of the characteristics of criminal act as such. On the other hand, the awareness of doing wrong is not necessary for intent. Depending on the level of the knowledge and will components, the German legal science distinguishes three types of intent. ${ }^{22}$

${ }^{20}$ See $\S 15$ of the German Strafgesetzbuch: Only a deliberate action is punishable if the law does not explicitly threaten a negligent action with punishment. See Strafgesetzbuch [1998-11-13]. BGBl. I S. 3322, last changed by law on July 10, 2020 (BGBl. I S. 1648).

${ }^{21}$ See WOLTER, J. Adäquanz- und Relevanztheorie: Zugleich ein Beitrag zur objektiven Erkennbarkeit beim Fahrlässigkeitsdelikt. Goltdammer's Archiv für Strafrecht. 1977, pp. 257-274. ISSN 0017-1956; ZIPF, H. Kriminalpolitische Überlegungen zur Entkriminalisierung der fahrlässigen Körperverletzung. In: E. SCHLÜCHETER and K. LAUBENTHAL, Hrsg. Recht und Kriminalität: Festschrift für Friedrich-Wilhelm Krause zum 70. Geburtstag. 1. Aufl. Köln: Heymann, 1990, pp. 437-447. ISBN 3-452-21890-2; TOEPEL, F. Kausalität und Pflichtwidrigkeitszusammenhang beim fahrlässigen Erfolgsdelikt [online]. 1. Aufl. Berlin: Duncker \& Humblot, 1992. 244 p. [cit. 2020-07-24]. Strafrechtliche Abhandlungen: Neue Folge, Band 75. ISBN 978-3-428-47412-7. Available at: https://doi.org/10.3790/ 978-3-428-47412-7; TIEDEMANN, K. Der Allgemeine Teil des Strafrechts im Lichte der europäischen Rechtsvergleichung. In: A. ESER, U. SCHITTENHELM and H. SCHUMANN, Hrsg. Festschrift für Theodor Lenckner zum 70. Geburtstag. 1. Aufl. München: C. H. Beck, 1998, pp. 411-434. ISBN 3-406-43842-3; ROXIN, C. Pflichtwidrigkeit und Erfolg bei fahrlässigen Delikten. Zeitschrift für die gesamte Strafrechtswissenschaft [online]. 1962, Jg. 74, Nr. 3, pp. 411-444 [cit. 2020-07-24]. ISSN 1612-703X. Available at: https://doi.org/10. 1515/zstw.1962.74.3.411; ROXIN, C. Zur Problematik des Schuldstrafrechts. Zeitschrift für die gesamte Strafrechtswissenschaft [online]. 1984, Jg. 96, Nr. 3, pp. 641-660 [cit. 202007-24]. ISSN 1612-703X. Available at: https://doi.org/10.1515/zstw.1984.96.3.641; R0XIN, C. Bemerkungen zum Regreßverbot. In: H.-H. JESCHECK and T. VOGLER, Hrsg. Festschrift für Herbert Tröndle zum 70. Geburtstag am 24. August 1989 [online]. 1. Aufl. Berlin; New York: De Gruyter, 1989, pp. 177-200 [cit. 2020-07-24]. ISBN 978-3-11-089207-9. Available at: https://doi.org/10.1515/9783110892079-011; and ROXIN, C. Die Lehre von der objektiven Zurechnung. Chengchi Law Review. 1994, vol. 50, pp. 219-257. ISSN 10239820.

${ }^{22}$ See BINDING, K. Die Normen und ihre Übertretung: Band I: Normen und Strafgesetze. 4. Aufl. Leipzig: Meiner, 1922. 508 p.; BINDING, K. Die Normen und ihre Übertretung: Band II: Schuld und Vorsatz. 1. Aufl. Leipzig: Engelmann, 1877. 640 p.; BINDING, K. Die Normen und ihre Übertretung: Band IV: Die Fahrlässigkeit. 1. Aufl. Leipzig: Meiner, 1919. 
The first type of intent is the so-called purpose or dolus directus of the first degree. In its borders, the perpetrator depends on the achieving of the goal he/she set for himself/herself. This purposeful will is the dominant moment of intention. It presupposes that the perpetrator at least thinks that the realization of the planned situation is possible. The second type of intent is the so-called certain knowledge or dolus directus of the second degree. In this case, the perpetrator is certain that he/she will achieve the goal. This secure knowledge is the dominant moment here. Those who safely assume that they will bring a change in the outside world and still continue to act will at least accept this change (in this respect, the will component is inevitable, if only in a weak form). And finally - dolus eventualis as the third type of intent, in the case of which the perpetrator believes that the offense can be committed and agrees with that. Here, because the intellectual and voluntary sides are not mutually dependent, both sides must be developed and proven from the case. ${ }^{23}$

Negligent action is only punishable where the law expressly criminalizes such activity. This is primarily the case of impairments to life and health as well as of bringing common danger to the public. However, modern legislation tends to create more negligent types of offense, while often does not make every negligence sufficient, but presupposes gross negligence ("recklessness"). Behaviour is contrary to due diligence under the following two conditions: a) it must be foreseeable that the behaviour can lead to a certain consequence under the given circumstances; b) it must be an unauthorized risk - below a certain threshold, dangers are tolerated by the legal system. ${ }^{24}$

681 p.; and BINDING, K. Die Schuld im deutschen Strafrecht: Vorsatz, Irrtum, Fahrlässigkeit. 1. Aufl. Leipzig: Meiner, 1919.164 p.

${ }^{23}$ See GEPPERT, K. Zur Abgrenzung von bedingtem Vorsatz und bewusster Fahrlässigkeit. Juristische Ausbildung. 1986, pp. 610-613. ISSN 0170-1452; HELLMANN, U. Einverständliche Fremdgefährdung und objektive Zurechnung. In: B. SCHÜNEMANN, H. ACHENBACH, W. BOTTKE, B. HAFFKE and H.-J. RUDOLPHI, Hrsg. Festschrift für Claus Roxin zum 70. Geburtstag am 15. Mai 2001 [online]. 1. Aufl. Berlin; Boston: De Gruyter, 2001, pp. 271-286 [cit. 2020-07-24]. ISBN 978-3-11-087702-1. Available at: https://doi.org/10.1515/9783 110877021.271; HERZBERG, R. D. Die Abgrenzung von Vorsatz und bewusster Fahrlässigkeit - ein Problem des objektiven Tatbestandes. Juristische Schulung. 1986, pp. 249262. ISSN 0022-6939; and HERZBERG, R. D. Die Sorgfaltswidrigkeit im Aufbau der fahrlässigen und der vorsätzlichen Straftat. Juristenzeitung. 1987, Jg. 42, Nr. 11, pp. 536-541. ISSN 0022-6882.

${ }^{24}$ See JÄHNKE, B. Grundlagen der strafrechtlichen Haftung für fahrlässiges Verhalten: Zugleich Bemerkungen zu Ellen Schlüchters Grenzen strafbarer Fahrlässigkeit. In: G. DUTTGE, G. GEILEN, L. MEYER-GOSSNER and G. WARDA, Hrsg. Gedächtnisschrift für Ellen Schlüchter. 1. Aufl. Köln: Heymanns, 2002, p. 99. ISBN 3-452-25164-0; and JESCHECK, H.- 
The Slovak ${ }^{25}$ and Polish ${ }^{26}$ definitions of intentional and unintentional offenses have far-reaching similarities. In particular, dolus directus constitutes a single category within them, without distinguishing between two distinct levels. In turn, the definition of negligence clearly separates its conscious and unconscious forms. ${ }^{27}$ In the both legal orders, there are references to the forms of the perpetrator's mental experience, which combine the element of deliberate performance of an act with its further, unintentional consequences. The perpetrator is liable in such cases on more severe punishment. ${ }^{28}$

H. Aufbau und Behandlung der Fahrlässigkeit im modernen Strafrecht. 1. Aufl. Freiburg im Breisgau: Schulz, 1965. 31 p.

${ }^{25}$ See $\S 15$ of the Slovak Trestný zákon: A criminal offense is committed intentionally if the offender a) wished to violate or to jeopardize an interest protected by this Act in the manner specified in this Act, or b) was aware that his/her actions could cause such a breach or threat and he/she was settled with this. See also § 16 of the Slovak Trestný zákon: A criminal offense is committed through negligence if the offender a) knew that he/she could, in the manner specified in this Act, violate or jeopardize the interest protected by this Act, but without reasonable grounds he/she relied on such breach or threat, or b) did not know that his/her actions could cause such a breach or threat, although he/she should and could have known about it given the circumstances and his/her personal circumstances. See Act No. 300/2005 Coll. of 20 May 2005 the Criminal Code [The Criminal Code of the Slovak Republic].

${ }^{26}$ See Article 8 of the Polish Kodeks karny: A crime may be committed only with intent; the misdemeanour may also be committed negligently if the law so stipulates. See also Article 9 of the Polish Kodeks karny: $\S 1$. A prohibited act is committed with intent when the perpetrator has the will to commit it, that is when he/she is willing to commit or foreseeing the possibility of perpetrating it, he/she accepts it; $\S 2$. A prohibited act is committed negligently when the perpetrator, not having the intent to commit it, nevertheless does so because he/she is not careful in the manner required under the circumstances, although he/she should or could have foreseen the possibility of committing the prohibited act; $\S 3$. The perpetrator shall be liable to a more severe liability which, according to the law, depends on a certain consequence of a prohibited act if he/she has and could have foreseen such a consequence. See Ustawa z dnia 6 czerwca 1997 r. - Kodeks karny. Dziennik Ustaw 2019, item 1950, 2128; and Dziennik Ustaw 2020, item 568, 875, 1086.

${ }^{27}$ See ZAWŁOCKI, R. Nieumyślność jako podstawa odpowiedzialności karnej - w poszukiwaniu kompromisu. Monitor Prawniczy. 2008, vol. 16, nr 11, pp.567-577. ISSN 12306509.

${ }^{28}$ See Decision of the Supreme Court of the Republic of Poland Ref. No. V KK 87/05 [2005-0725]. LEX no. 152493; Judgement of the Court of Appeal in Szczecin Ref. No. II AKa 170/14 [2014-10-16]. LEX no. 1544938. See also ANDREJEW, I. Ustawowe znamiona czynu: Typizacja i kwalifikacja przestępstw. 1. wyd. Warszawa: Wydawnictwa Prawnicze, 1978, p. 200 and following; REJMAN, G. Teorie i formy winy w prawie karnym. 1. wyd. Warszawa: Wydawnictwo Prawnicze, 1980, p. 187 and following. ISBN 83-219-0059-3; REJMAN, G. Wina w konstrukcji kodeksu karnego z 1997 roku. In: G. BAŁTRUSZAJTYS, ed. Prawo wczoraj i dziś: Studia dedykowane profesor Katarzynie Sójce-Zielińskiej. 1. wyd. Warszawa: Liber, 2000, pp. 261-277. ISBN 83-7206-029-0; GIEZEK, J. Naruszenie obowiązku ostro- 
A characteristic feature of behaviour of the vehicle driver in this case is the awareness of the possibility of implementing the features of a prohibited act. It is an intellectual component of the intent in all its forms (only in the case of the certain knowledge or the dolus directus of the second degree replaced by the awareness of the necessity of the realized features). The only problem is that the same intellectual elements are present in the case of the conscious negligence. It is then accompanied by a completely different volitional component which comes down to the lack of even consent to the implementation of features of a prohibited act, and thus in practice to the lack of acceptance for the perspective of the implementation of the objective elements of such behaviour. The difference between dolus directus and dolus eventualis occurs exclusively "in the perpetrator's head", which makes it complicated to efficiently reconstruct the shape of his/her mental experience. ${ }^{29}$

The method used in this case by the representatives of both literature and practice of the judiciary is the so-called concept of the objective manifestation. Since the volitional component of a possible intent is agreeing to the implementation of the components of a prohibited act, the way to exclude intentional behaviour is to undertake activities that, in the subjective opinion of the perpetrator, should eliminate the possibility of committing a crime or at least should significantly reduce its probability. Completion of this requirement is, in a way, visual evidence of the lack of reconciliation with the consequences of behaviour covered by the structure of a prohibited act. If they do occur, it is a consequence of the perpetrator's own error, which, due to the failure to observe the required precautions, causes an unacceptable risk for the legal good. ${ }^{30}$

żności jako przesłanka urzeczywistnienia znamion przestępstwa nieumyślnego. Państwo i Prawo. 1992, vol. 47, nr 1, pp. 65-75. ISSN 0031-0980; GIEZEK, J. 0 tendencjach do subiektywizowania bezprawności oraz obiektywizowania winy we współczesnym prawie karnym. In: Z. SIENKIEWICZ, ed. Wybrane zagadnienia reformy prawa karnego. 1. wyd. Wrocław: Wydawnictwo Uniwersytetu Wrocławskiego, 1997, pp. 9-19. ISBN 83-2291576-4; BURDA, E., J. ČENTÉŠ, J. KOLESÁR, J. ZÁHORA, et al. Trestný zákon: Všeobecná čast': Komentár: I. diel. 1. vyd. Praha: C. H. Beck, 2010. 1106 p. ISBN 978-80-7400-324-0; IVOR, J. et al. Trestné právo hmotné: Všeobecná čast'. 1. vyd. Bratislava: Iura Edition, 2006. 530 p. ISBN 80-8078-099-4; and MENCEROVÁ, I., L. TOBIÁŠOVÁ, Y. TURAYOVÁ, et al. Trestné právo hmotné: Všeobecná čast'. 1. vyd. Šamorín: Heuréka, 2013. 478 p. ISBN 97880-89122-86-8.

${ }^{29}$ See Judgement of the Bundesgerichtshof Ref. No. 4 StR 482/19 [2020-06-18].

${ }^{30}$ See TAYLOR, G. Concepts of Intention in German Criminal Law. Oxford Journal of Legal Studies [online]. 2004, vol. 24, no. 1, pp. 106-107 [cit. 2020-07-24]. ISSN 1464-3820. Available at: https://doi.org/10.1093/ojls/24.1.99; PRZESŁAWSKI, T. Funkcja czynnika 
Thus, it can be assumed that the lack of any activity that would minimize the level of the threat caused by the perpetrator is a clear indication that the consequences of the perpetrator's behaviour indicated by the features of a prohibited act are accepted by him/her. The more serious level of danger caused by the perpetrator's behaviour, the less doubts should arise from the conviction that the perpetrator who does not try to minimize the threats to the legal good agrees not only with the threat, but also with the destruction of such good.

In conclusion - in the case of the perpetrator driving a motor vehicle in an extremely risky manner, who, in addition, does not take any actions aimed at minimizing the danger, e.g. to guarantee him/her the possibility of reacting to suddenly appearing specific sources of threats, it gives sufficient grounds to assume that he/she, in fact, at least accepts the implementation of the features of a prohibited act and, therefore, that his/her behaviour is driven by at least possible intent.

\section{Law enforcement practice in cases of traffic offenses}

Analysing the three issues that are the subject of assessment in this paper, we will primarily start by referring to the events that took place in Berlin. It is in this case that we can use not only the findings of the investigation, but also the material collected in the course of two proceedings before the National Court in Berlin and the German Supreme Court.

The fact to which the courts of both instances drew attention was the content of the psychological experience of the finally convicted H. Significant in the opinion of the German Supreme Court was his almost demonstrative disregard for safety requirements related to driving a car. He did not fasten his seat belts, convinced that modern elements of his vehicle's structure, such as crush zones or airbags, would save his life in a collision with another road user. He was convinced that the class of his vehicle and equipment were a guarantee of survival for him, which significantly weakened the strength of the argument according to which concern for one's own life and health restrains the perpetrator from consent to causing a serious road accident. His opinion was additionally strengthened by

psychicznego w konstrukcji czynu zabronionego i formach winy. Studia Iuridica. 2008, nr 48, p. 228. ISSN 0137-4346; CIEŚLAK, M. Polskie prawo karne: Zarys systemowego ujęcia. 3. wyd. Warszawa: Wydawnictwa Prawnicze PWN, 1995, p. 305. ISBN 83-86702-117; and SZERER, M. W sprawie zamiaru ewentualnego. Państwo i Prawo. 1959, vol. 14, nr 3, p. 455. ISSN 0031-0980. 
the only partially justified conviction about his own above-average skills, excellent reflex, short reaction time and other psychophysical features that made him, in his own opinion, an excellent driver.

In the course of the proceedings, it was possible to create a credible psychological portrait of $\mathrm{H}$. whose important elements, apart from the anxiety deficit, were the need for competition and the desire to constantly confirm his own worth in confrontation with others. This adds credibility to the hypothesis that the will to win in an improvised rally was more important to him than taking care of his own safety. In addition, as it was already mentioned, the cars of participants in illegal races are often modified in a way that increases safety in the event of a collision. The chance of surviving and avoiding serious injury from such an incident is incomparably higher thanks to additional reinforcements, cages made of resistant materials to protect the driver and similar measures.

To attribute to $\mathrm{H}$. not homicide, but its qualified form - murder, also required the indication of an additional element of his behaviour, allowing to treat the perpetrator with particular severity. In this case, this element is not related to the motivation, but to the perpetrator's way of acting - he should act by means dangerous to the public. Also this element in the discussed case does not seem to raise any serious doubts. It can even be stated that in the case of illegal car races, it usually accompanies the assessed behaviour. Of course, such a threat does not have to come true, but if the consequence of the perpetrator's act is the death of a person, it will be relatively easy to bring a murder charge under the German criminal law system.

In the light of the judgement issued by the German Supreme Court, the fact that the appeal brought by $\mathrm{N}$. was taken into account should be positively assessed. The substantiation of the judgement rightly indicates some level of astonishment that the National Court in Berlin believes the victim's death can be attributed also to the perpetrator who avoided the collision. The circumstances of the event do not give grounds for accepting that his behaviour would additionally increase the danger for the legal goods; for making $\mathrm{H}$. want to catch up with him and to win the race it is not a sufficient basis for such statement.

It is also impossible to defend the conviction expressed by the $\mathrm{Na}$ tional Court in Berlin about the fulfilment of the criteria of a prohibited act in the form of an agreement. Although such agreement can be found between both participants of the race on the issue of bringing a threat to 
other road participants by illegal races, and perhaps even tacit consent to the existence of a far-reaching effect, it is impossible to consider their behaviours at the time of the emergence of this effect as collective. As rightly emphasized by the German Supreme Court, mere participation in an illegal undertaking does not mean that to all its participants can be assigned all objectively occurring consequences.

Referring to the attribution of complicity in each of the three discussed cases, it should be emphasized that such a qualification does not raise any doubts in the case of assigning responsibility for the deliberate introduction of common danger. Such behaviour, described in $\S 315 \mathrm{c}$ of the German Strafgesetzbuch, § 284 of the Slovak Trestný zákon or the Article 173 of the Polish Penal Code, may be committed under conditions of complicity. It is perceived in the German, ${ }^{31}$ Slovak $^{32}$ and Polish ${ }^{33}$ criminal laws as a conjunction of two conditions - an action taken jointly and an agreement (even implicitly).

Despite the similarity of the regulations relating to complicity, the three orders of criminal law in question are distinguished by a certain significant circumstance which is important for the attribution of criminal liability to participants of illegal races. As it should be assumed, the German and Slovak literatures ${ }^{34}$ relatively unanimously reject the possibility of complicity in unintentional crimes, assuming that the agreement between the perpetrators should include all the features of a prohibited act. Thus, they must be united by the awareness of the possibility of jointly committing a crime and at least must consent to it.

\footnotetext{
${ }^{31}$ See $\S 25$ of the German Strafgesetzbuch: (1) A perpetrator is punished if he/she commits the crime himself/herself or through someone else; (2) If several commit the offense jointly, each will be punished as a perpetrator (accomplice). See Strafgesetzbuch [199811-13]. BGBl. I S. 3322, last changed by law on July 10, 2020 (BGBl. I S. 1648).

${ }^{32}$ See $\S 20$ of the Slovak Trestný zákon: If a criminal offence was committed by two or more persons acting in conjunction (accomplices), each of them has the same criminal liability as the single person who would commit such a criminal offence. See Act No. 300/2005 Coll. of 20 May 2005 the Criminal Code [The Criminal Code of the Slovak Republic].

${ }^{33}$ See Article 18 of the Polish Kodeks karny: $\S 1$. Responsible for the perpetration is not only the one who performs the prohibited act alone or jointly and in agreement with another person, but also the one who directs the execution of the prohibited act by another person or by using another person's dependence on himself/herself, orders such a person to perform such an act. See Ustawa z dnia 6 czerwca 1997 r. - Kodeks karny. Dziennik Ustaw 2019, item 1950, 2128; and Dziennik Ustaw 2020, item 568, 875, 1086.

${ }^{34}$ See MAŠL'ANYOVÁ, D. et al. Trestné právo hmotné: Všeobecná a osobitná čast'. 3. aktualiz. a dopln. vyd. Plzeň: Vydavatelství a nakladatelství Aleš Čeněk, 2019, p. 128. ISBN 978-807380-772-6.
} 
The Polish literature, however, starting from very similarly formulated regulations, goes in a different direction. Most of its representatives assume that the perpetrators' agreement may only cover a joint breach of the principle of cautious conduct with the legal good and, therefore, careless behaviour, which may consequently induce an effect that the perpetrators do not agree with. ${ }^{35}$ Paradoxically, this means that assigning an unintentional result in the form of the death of a victim of an illegal race to all its participants is a much simpler than trying to assign an intent to each of them. It is enough for them to be aware of the danger of such competition and to increase its level by joining the number of participants. ${ }^{36}$

When assessing the reaction of the Slovak prosecutor's office to the incident in the vicinity of Dolný Kubín, it should be emphasized that $\S 284$ (3) of the Slovak Penal Code is a relatively uncontroversial reaction to the perpetrators' behaviours. In particular, there is no doubt about the possibility of using the construction of complicity. The mere participation in an illegal race, a relatively narrow road running in mountainous terrain create a generally dangerous situation; the agreement of the perpetrators and the increased risk caused by each of them by joining the race behind the wheel of another vehicle give full grounds for recognizing the cooperation of all drivers. From this perspective, the result in the form of death of another participant of traffic is predictable; the attribution of responsibility does not require consent to its result.

It is significant that the Slovak law enforcement did not go a step further, attributing to the perpetrators or only to the driver of the Porsche L.

${ }^{35}$ See G. Bogdan in ZOLL, A. ed. Kodeks karny: Część szczególna: Komentarz: Tom II: Komentarz do art. 117 - 277 k.k. 2. wyd. Warszawa: Zakamycze, 2006. 1438 p. ISBN 83-7444252-2; BUCHAŁA, K. Niektóre problemy wykładni znamion przestępstw przeciwko bezpieczeństwu w komunikacji. Prokuratura i Prawo. 1998, nr 11-12, pp. 7-17. ISSN 12332577; and BUCHAŁA, K. Niektóre zagadnienia nowelizacji prawa karnego. Państwo i Prawo. 1996, vol. 51, nr 3, pp. 3-12. ISSN 0031-0980.

${ }^{36}$ See STEFAŃSKI, R. A. Wypadek w komunikacji jako przestępstwo w nowym kodeksie karnym. Prokuratura i Prawo. 1998, nr 10, pp. 47-70. ISSN 1233-2577; STEFAŃSKI, R. A. Przestępstwa przeciwko bezpieczeństwu powszechnemu i w komunikacji: Rozdział XX i XXI Kodeksu karnego: Komentarz. 1. wyd. Warszawa: C. H. Beck, 2000, p. 98 and following. ISBN 83-7110-239-9; DĄBROWSKA-KARDAS, M. and P. KARDAS. Odpowiedzialność za spowodowanie wypadku komunikacyjnego w świetle regulacji nowego k.k. z 1997 r.: Część II. Palestra. 1999, nr 3-4, pp. 36-41. ISSN 0031-0344; and P. Kardas in GIEZEK, J. ed. Przestępstwo - kara - polityka kryminalna: Problemy tworzenia i funkcjonowania prawa: Księga jubileuszowa z okazji 70. rocznicy urodzin Profesora Tomasza Kaczmarka. 1. wyd. Kraków: Zakamycze, 2006, p. 360. ISBN 83-7444-283-2. 
who was directly involved in the collision the result in the form of death of the victim. To some extent, the relatively severe threat of punishment provided for in $\S 284$ (3) of the Slovak Penal Code may be considered the cause. The penalty imposed for intentional murder would not be more severe in practice, as it would be difficult to find the grounds indicated in $\S 144$ and $\S 145$ of the Slovak Penal Code that would increase the threat, and the construction of $\S 41$ (1) of the said Code could lead to blurring the element associated with bringing common danger in the legal qualification.

Obviously, this does not change the fact that the circumstances in favour of assigning the perpetrator a deliberate effect in the form of the victim's death seem in this case just as justified as in the situation in Berlin. According to the Slovak criminal law, committing such an act in a manner that poses a common danger is not, however, the basis for accepting more severe liability for murder. Thus, the distribution of emphasis between indicating the deliberate nature of the attack and emphasizing the universal threat brought by the perpetrators, which is allowed by $\S 284$ (3) of the Slovak Penal Code, certainly requires a deeper reflection.

In terms of the Polish criminal law, the situation is more complicated. ${ }^{37}$ The offense of traffic disaster described in the Article 173 of the Polish Criminal Code will apply only in the case when life or health of many people or property in large size is endangered in a real road collision. Therefore, an incident involving one or two perpetrators and two victims will not fall into this category. Traditionally, the basis of liability in such cases is the Article $177 \S 2$ of the Polish Criminal Code, which provides the responsibility for negligent causing of death, although the context of road traffic determines a clearly more severe penalty than provided for causing such an effect in another way. ${ }^{38}$

\footnotetext{
${ }^{37}$ See DYMIŃSKA, Z. M. and R. PAWLIK. The Space of Validity the Polish Criminal Code Act from the Perspective of European Integration - the International Context (1). In: A. SIPKO and M. HRNČIAR, eds. Národná a medzinárodná bezpečnost' 2015 [online]. 1. vyd. Liptovský Mikuláš: Akadémia ozbrojených síl generála Milana Rastislava Štefánika, 2015, pp. 94-105 [cit. 2020-07-24]. ISBN 978-80-8040-515-1. Available at: http://www.aos.sk/ struktura/katedry/kbo/NMB2015/Zbornik_NMB_2015.pdf.

${ }^{38}$ See STEFAŃSKI, R. A. Przestępstwa przeciwko bezpieczeństwu w ruchu lądowym, wodnym lub powietrznym w projekcie kodeksu karnego. Problemy Praworządności. 1990, nr 8-9, pp. 38-39. ISSN 0137-8643; STEFAŃSKI, R. A. Prawo o ruchu drogowym: Komentarz. 3. wyd. Warszawa: Wolters Kluwer, 2008, pp. 2-55. ISBN 978-83-7601-056-4; STEFAŃSKI, R. A. Przestępstwa przeciwko bezpieczeństwu powszechnemu i w komunikacji:
} 
An attempt to reach for the provisions governing liability for wilful causing of death leads to the Article 148 of the Polish Penal Code. ${ }^{39}$ Characteristically, also in this case there is a doubt as to whether the basis of liability will be the basic type of homicide, or the possibility of assigning a murder threatened by a more severe penalty will come into play. Much depends on the interpretation of the concept of "motivation deserving special condemnation" which determines the higher responsibility for this act. Although in the discussed case the allegation covered the standard qualification under the Article $148 \S 1$ of the Polish Penal Code, there is an interpretation in the Polish jurisprudence which recognizes the motivation to commit murder "for entertainment", "out of curiosity", or even without any consciously quoted reason. The thesis that the same categories may include killing a man (also cum dolo eventuali, what the Polish judicature clearly allows), motivated by the will to win illegal races, experiencing an adventure or improving one's self-esteem, does not seem unfounded. 40

Rozdział XX i XXI Kodeksu karnego: Komentarz. 1. wyd. Warszawa: C. H. Beck, 2000, pp. 236-237. ISBN 83-7110-239-9; STEFAŃSKI, R. A. Wykroczenia drogowe: Komentarz. 1. wyd. Kraków: Zakamycze, 2005, pp. 140-141. ISBN 83-7444-215-8; and ZOLL, A. Odpowiedzialność karna kierowcy za spowodowanie wypadku i nieudzielenie pomocy jego ofierze. Wojskowy Przegląd Prawniczy. 1969, nr 1, pp. 17-28. ISSN 0137-7272. See also ZOLL, A. Kilka uwag w związku z charakterem prawnym norm sankcjonujących wynikających z art. 178 § 1 k.k. In: A. MICHALSKA-WARIAS, I. NOWIKOWSKI and J. PIÓRKOWSKAFLIEGER, eds. Teoretyczne i praktyczne problemy współczesnego prawa karnego: Księga jubileuszowa dedykowana Profesorowi Tadeuszowi Bojarskiemu. 1. wyd. Lublin: Wydawnictwo Uniwersytetu Marii Curie-Skłodowskiej, 2011, pp.635-642. ISBN 978-83-7784000-9; BACHRACH, A. Przestępstwa i wykroczenia drogowe w nowym prawie polskim. 1. wyd. Warszawa: Państwowe Wydawnictwo Naukowe, 1974, p. 173; and PAWLIK, R. Odpowiedzialność sprawcy wypadku komunikacyjnego za spowodowanie tzw. lekkiego uszkodzenia ciała. Paragraf na Drodze. 2003, nr 2, pp. 5-13. ISSN 1505-3520.

${ }^{39}$ See DASZKIEWICZ, K. Przestępstwa przeciwko życiu i zdrowiu: Rozdział XIX Kodeksu karnego: Komentarz. 1. wyd. Warszawa: C. H. Beck, 2000. 440 p. ISBN 83-7110-247-X; and POHL, Ł. O stosunku między zmodyfikowanym typem czynu zabronionego pod groźbą kary a leżącą u jego podstaw normą sankcjonowaną. Ius Novum. 2010, nr 1, pp. 7-22. ISSN 1897-5577.

${ }^{40}$ See Judgement of the Court of Appeal in Warsaw Ref. No. II AKa 435/96 [1997-01-28]. Prok. i Pr. 1998, no. 5, item 23; Judgement of the Court of Appeal in Gdańsk Ref. No. II Aka 92/13 [2013-04-18]. LEX no. 1314694, with gloss of M. Budyn-Kulik, WPP 2014, no. 3, p. 112 and following; BUDYN, M. Motywacja zasługująca na szczególne potępienie (próba analizy). Prokuratura i Prawo. 2000, nr 9, pp. 23-43. ISSN 1233-2577; Judgement of the Court of Appeal in Lublin Ref. No. II AKa 12/99 [1999-04-27]. Prok. i Pr. 2001, no. 5, item 27, with approving gloss of M. Budyn, OSP 2000, no. 9, item 127; and BEDNARZAK, J. Kryteria ocenne zamiaru zabójstwa w sprawach o usiłowanie pozbawienia życia. Studia 


\section{Conclusions}

The essence of the role of criminal law in a democratic state ruled by law is the thought expressed by Seneca: "Nemo prudens punit quia peccatum est sed ne peccetur" - "No reasonable person punishes because a crime was committed, but to not be committed". The analysis of all three cases, which became the basis of this paper, leads to the conviction that creating types of crimes protecting traffic safety instead of using types of crimes against life and health, without taking into account the fact that they occurred in road traffic, is not goal-oriented and does not serve to fulfil the primarily protective functions of criminal law. The issue of responsibility for such events should be reviewed due to the fundamental changes in both the road traffic and the behaviours of its participants which are becoming more and more risky and aggressive. It is important that the perpetrators, exactly as in all three described cases, have a significant advantage over other participants of the traffic and, at the same time, have full awareness of this dominance, what they brutally use and which, in turn, leads to such events as those outlined in this study. ${ }^{41}$

It seems necessary to shape, in the coming years, a commonly accepted model of criminal liability under which behaviours generating a common threat to legal goods, while, at the same time, characterized by the lack of actions objectively indicating the will of the perpetrator to protect them should be perceived as intentional attacks against this goods. In the case of road traffic offenses, it is appropriate to consider behaviour that poses a serious risk to other road users as an act intentionally directed against human life and health.

Perpetrators participating in illegal races behind the wheel of highclass cars, equipped with factory mechanisms increasing the level of user safety, often improved and supplemented by the drivers themselves are more prone to excessively risky behaviour. The sense of personal safety is enhanced by the ambivalent approach to the dangers of daring, ex-

Kryminologiczne, Kryminalistyczne i Penitencjarne. 1975, nr 3, p. 115 and following. ISSN 0137-5458.

${ }^{41}$ See PAWLIK, R. Sanctions from Perspective of Ius Puniendi: Between Criminal Liability and Liability for a Misdemeanour, and Administrative Liability - the Example of Poland. Societas et iurisprudentia [online]. 2016, vol. 4, no. 3, pp. 72-116 [cit. 2020-07-24]. ISSN 1339-5467. Available at: http://sei.iuridica.truni.sk/international-scientific-journal/ archive/issue-2016-03/sanctions-from-perspective-of-ius-puniendi-between-criminalliability-and-liability-for-a-misdemeanour-and-administrative-liability-the-example-ofpoland/. 
tremely risky driving and allows for a disrespectful assessment of the effects of a collision caused by a speeding two-ton vehicle with a car of an average traffic participant. It would be a mistake not to see in their behaviours an agreement to even the most far-reaching effects.

The current state of affairs not only does not serve the correct criminal reaction to the perpetrators who have already been identified, but it also does not help to shape attitudes preventing similar events that could happen in the future. Developing of appropriate forms of legal reaction to the described offenses is, of course, a complex process and the abovementioned questions are only an attempt to indicate the most important problems that the science of criminal law must face. ${ }^{42}$ It is appropriate to express the hope that this issue will receive a well-deserved attention in the near future.

\section{References}

Act No. 300/2005 Coll. of 20 May 2005 the Criminal Code [The Criminal Code of the Slovak Republic].

ANDREJEW, I. Ustawowe znamiona czynu: Typizacja i kwalifikacja przestępstw. 1. wyd. Warszawa: Wydawnictwa Prawnicze, 1978. 315 p.

BACHRACH, A. Przestępstwa i wykroczenia drogowe w nowym prawie polskim. 1. wyd. Warszawa: Państwowe Wydawnictwo Naukowe, 1974. $464 \mathrm{p}$.

BEDNARZAK, J. Kryteria ocenne zamiaru zabójstwa w sprawach o usiłowanie pozbawienia życia. Studia Kryminologiczne, Kryminalistyczne i Penitencjarne. 1975, nr 3, p. 115 and following. ISSN 0137-5458.

BINDING, K. Die Normen und ihre Übertretung: Band I: Normen und Strafgesetze. 4. Aufl. Leipzig: Meiner, 1922.508 p.

BINDING, K. Die Normen und ihre Übertretung: Band II: Schuld und Vorsatz. 1. Aufl. Leipzig: Engelmann, 1877.640 p.

BINDING, K. Die Normen und ihre Übertretung: Band IV: Die Fahrlässigkeit. 1. Aufl. Leipzig: Meiner, 1919.681 p.

BINDING, K. Die Schuld im deutschen Strafrecht: Vorsatz, Irrtum, Fahrlässigkeit. 1. Aufl. Leipzig: Meiner, 1919.164 p.

${ }^{42}$ See PAWLIK, R. Kontrawencjonalizacja w polskim prawie karnym i wykroczeń: Analiza teoretyczno-dogmatyczna na tle porównawczym. 1. wyd. Kraków: Oficyna Wydawnicza AFM, 2016, p. 455 and following. ISBN 978-83-65208-39-2. 
BOCKELMANN, P. Der Schuldgehalt des menschlichen Versagens im Straßenverkehr. Deutsches Autorecht. 1964, p. 288 and following. ISSN 0012-1231.

BÖHMER, E. Der Vertrauensgrundsatz im Straßenverkehr in der neueren Rechtsprechung. Monatsschrift für deutsches Recht. 1964, p. 100 and following. ISSN 0340-1812.

BÖHMER, E. Der Vertrauensgrundsatz im Straßenverkehr in der Rechtsprechung. Juristische Rundschau. 1967, p. 291 and following. ISSN 0022-6920.

BUCHAŁA, K. Niektóre problemy wykładni znamion przestępstw przeciwko bezpieczeństwu w komunikacji. Prokuratura i Prawo. 1998, nr 11-12, pp. 7-17. ISSN 1233-2577.

BUCHAŁA, K. Niektóre zagadnienia nowelizacji prawa karnego. Państwo i Prawo. 1996, vol. 51, nr 3, pp. 3-12. ISSN 0031-0980.

BUDYN, M. Motywacja zasługująca na szczególne potępienie (próba analizy). Prokuratura i Prawo. 2000, nr 9, pp. 23-43. ISSN 1233-2577.

BURDA, E., J. ČENTÉŠ, J. KOLESÁR, J. ZÁHORA, et al. Trestný zákon: Všeobecná čast': Komentár: I. diel. 1. vyd. Praha: C. H. Beck, 2010. 1106 p. ISBN 978-80-7400-324-0.

CIEŚLAK, M. Polskie prawo karne: Zarys systemowego ujęcia. 3. wyd. Warszawa: Wydawnictwa Prawnicze PWN, 1995. 492 p. ISBN 83-8670211-7.

DASZKIEWICZ, K. Przestępstwa przeciwko życiu i zdrowiu: Rozdział XIX Kodeksu karnego: Komentarz. 1. wyd. Warszawa: C. H. Beck, 2000. 440 p. ISBN 83-7110-247-X.

DĄBROWSKA-KARDAS, M. and P. KARDAS. Odpowiedzialność za spowodowanie wypadku komunikacyjnego w świetle regulacji nowego k.k. z 1997 r.: Część II. Palestra. 1999, nr 3-4, pp. 35-51. ISSN 0031-0344.

Decision of the Supreme Court of the Republic of Poland Ref. No. V KZP 2/ 74 [1975-02-28]. OSNKW 1975, no. 3-4, item 33.

Decision of the Supreme Court of the Republic of Poland Ref. No. V KK 87/ 05 [2005-07-25]. LEX no. 152493.

DYMIŃSKA, Z. M. and R. PAWLIK. The Space of Validity the Polish Criminal Code Act from the Perspective of European Integration - the International Context (1). In: A. SIPKO and M. HRNČIAR, eds. Národná 
a medzinárodná bezpečnost' 2015 [online]. 1. vyd. Liptovský Mikuláš: Akadémia ozbrojených síl generála Milana Rastislava Štefánika, 2015, pp. 94-105 [cit. 2020-07-24]. ISBN 978-80-8040-515-1. Available at: http://www.aos.sk/struktura/katedry/kbo/NMB2015/ Zbornik_NMB_2015.pdf.

GEPPERT, K. Zur Abgrenzung von bedingtem Vorsatz und bewusster Fahrlässigkeit. Juristische Ausbildung. 1986, pp. 610-613. ISSN 01701452.

GIEZEK, J. ed. Przestępstwo - kara - polityka kryminalna: Problemy tworzenia i funkcjonowania prawa: Księga jubileuszowa z okazji 70. rocznicy urodzin Profesora Tomasza Kaczmarka. 1. wyd. Kraków: Zakamycze, 2006. 742 p. ISBN 83-7444-283-2.

GIEZEK, J. Naruszenie obowiązku ostrożności jako przesłanka urzeczywistnienia znamion przestępstwa nieumyślnego. Państwo i Prawo. 1992, vol. 47, nr 1, pp. 65-75. ISSN 0031-0980.

GIEZEK, J. 0 tendencjach do subiektywizowania bezprawności oraz obiektywizowania winy we współczesnym prawie karnym. In: Z. SIENKIEWICZ, ed. Wybrane zagadnienia reformy prawa karnego. 1. wyd. Wrocław: Wydawnictwo Uniwersytetu Wrocławskiego, 1997, pp. 9-19. ISBN 83-229-1576-4.

HELLMANN, U. Einverständliche Fremdgefährdung und objektive Zurechnung. In: B. SCHÜNEMANN, H. ACHENBACH, W. BOTTKE, B. HAFFKE and H.-J. RUDOLPHI, Hrsg. Festschrift für Claus Roxin zum 70. Geburtstag am 15. Mai 2001 [online]. 1. Aufl. Berlin; Boston: De Gruyter, 2001, pp. 271-286 [cit. 2020-07-24]. ISBN 978-3-11087702-1. Available at: https://doi.org/10.1515/9783110877021. 271.

HERZBERG, R. D. Die Abgrenzung von Vorsatz und bewusster Fahrlässigkeit - ein Problem des objektiven Tatbestandes. Juristische Schulung. 1986, pp. 249-262. ISSN 0022-6939.

HERZBERG, R. D. Die Sorgfaltswidrigkeit im Aufbau der fahrlässigen und der vorsätzlichen Straftat. Juristenzeitung. 1987, Jg. 42, Nr. 11, pp. 536-541. ISSN 0022-6882.

IVOR, J. et al. Trestné právo hmotné: Všeobecná čast'. 1. vyd. Bratislava: Iura Edition, 2006. 530 p. ISBN 80-8078-099-4. 
JÄHNKE, B. Grundlagen der strafrechtlichen Haftung für fahrlässiges Verhalten: Zugleich Bemerkungen zu Ellen Schlüchters Grenzen strafbarer Fahrlässigkeit. In: G. DUTTGE, G. GEILEN, L. MEYER-GOSSNER and G. WARDA, Hrsg. Gedächtnisschrift für Ellen Schlüchter. 1. Aufl. Köln: Heymanns, 2002, pp. 99-106. ISBN 3-452-25164-0.

JESCHECK, H.-H. Aufbau und Behandlung der Fahrlässigkeit im modernen Strafrecht. 1. Aufl. Freiburg im Breisgau: Schulz, 1965. 31 p.

Judgement of the Bundesgerichtshof Ref. No. 4 StR 399/17 [2018-03-01].

Judgement of the Bundesgerichtshof Ref. No. 4 StR 482/19 [2020-06-18].

Judgement of the Court of Appeal in Gdańsk Ref. No. II AKa 92/13 [201304-18]. LEX no. 1314694, with gloss of M. Budyn-Kulik, WPP 2014, no. 3, p. 112 and following.

Judgement of the Court of Appeal in Lublin Ref. No. II AKa 12/99 [1999-0427]. Prok. i Pr. 2001, no. 5, item 27, with approving gloss of M. Budyn, OSP 2000, no. 9, item 127.

Judgement of the Court of Appeal in Szczecin Ref. No. II AKa 170/14 [201410-16]. LEX no. 1544938.

Judgement of the Court of Appeal in Warsaw Ref. No. II AKa 435/96 [199701-28]. Prok. i Pr. 1998, no. 5, item 23.

Judgement of the Supreme Court of the Republic of Poland Ref. No. V KKN 303/97 [1998-11-04]. OSNKW 1998, no. 11-12, item 50, with gloss of K. J. Pawelec, Mon. Praw. 1999, no. 5.

Judgement of the Supreme Court of the Republic of Poland Ref. No. III KKN 231/98 [2000-03-08]. OSNKW 2000, no. 5-6, item 45, with approving glosses of J. Giezek, PiP 2001, no. 6; A. Górski, OSP 2001, no. 6; J. Majewski, OSP 2001, no. 10; and J. M. Iwaniec, Prokurator 2001, no. 4.

KOCHANOWSKI, J. Zagadnienia przestępstw drogowych i przeciwko bezpieczeństwu w komunikacji. 1. wyd. Warszawa: Naczelna Rada Adwokacka, 1990. 120 p.

MAREŠOVÁ, I. Poliak, ktorý bol účastníkom tragickej naháňačky na Orave, sa postavil pred súd. In: Noviny.sk [online]. 2019-06-06 [cit. 202007-24]. Available at: https://www.noviny.sk/krimi/446838-poliakktory-bol-ucastnikom-tragickej-nahanacky-na-orave-sa-postavilpred-sud. 
MAŠL'ANYOVÁ, D. et al. Trestné právo hmotné: Všeobecná a osobitná čast'. 3. aktualiz. a dopln. vyd. Plzeň: Vydavatelství a nakladatelství Aleš Čeněk, 2019. 642 p. ISBN 978-80-7380-772-6.

MENCEROVÁ, I., L. TOBIÁŠOVÁ, Y. TURAYOVÁ, et al. Trestné právo hmotné: Všeobecná čast'. 1. vyd. Šamorín: Heuréka, 2013. 478 p. ISBN 97880-89122-86-8.

OLSZEWSKI, M. Ochrona bezpieczeństwa drogowego w nowym kodeksie karnym. Palestra. 1970, nr 4, pp. 32-47. ISSN 0031-0344.

PAWLIK, R. Kontrawencjonalizacja w polskim prawie karnym i wykroczeń: Analiza teoretyczno-dogmatyczna na tle porównawczym. 1. wyd. Kraków: Oficyna Wydawnicza AFM, 2016. 673 p. ISBN 978-83-6520839-2.

PAWLIK, R. Odpowiedzialność sprawcy wypadku komunikacyjnego za spowodowanie tzw. lekkiego uszkodzenia ciała. Paragraf na Drodze. 2003, nr 2, pp. 5-13. ISSN 1505-3520.

PAWLIK, R. Sanctions from Perspective of Ius Puniendi: Between Criminal Liability and Liability for a Misdemeanour, and Administrative Liability - the Example of Poland. Societas et iurisprudentia [online]. 2016, vol. 4, no. 3, pp. 72-116 [cit. 2020-07-24]. ISSN 1339-5467. Available at: http://sei.iuridica.truni.sk/international-scientificjournal/archive/issue-2016-03/sanctions-from-perspective-of-iuspuniendi-between-criminal-liability-and-liability-for-a-misdemeanour-and-administrative-liability-the-example-of-poland/.

Pirátska jazda Poliakov: Súd rozhodol o poslednom z nich, ktorý má na tragédii najväčší podiel viny. In: Topky.sk [online]. 2019-06-07 [cit. 2020-07-24]. Available at: https://www.topky.sk/cl/100370/18004 01/Piratska-jazda-Poliakov--Sud-rozhodol-o-poslednom-z-nich--ktory-ma-na-tragedii-najvacsi-podiel-viny.

POHL, Ł. O stosunku między zmodyfikowanym typem czynu zabronionego pod groźbą kary a leżącą u jego podstaw normą sankcjonowaną. Ius Novum. 2010, nr 1, pp. 7-22. ISSN 1897-5577.

Polacy w porsche, ferrari i mercedesie spowodowali koszmarny wypadek na Słowacji [WIDE0]. In: Żywiec Nasze Miasto [online]. 2018-10-01 [cit. 2020-07-24]. Available at: https://zywiec.naszemiasto.pl/polacy-w-porsche-ferrari-i-mercedesie-spowodowali-koszmarny/ar/ c16-4823017. 
PRUSAK, F. and G. WOŚKO. Śmiertelne wypadki drogowe: Aspekty procesowe i medyczne. In: K. SŁAWIK, ed. Współczesna przestępczość: Problemy prawnokarne, kryminalistyczne i kryminologiczne. 1. wyd. Szczecin: JotA, 1996, pp. 160-166. ISBN 83-901965-4-9.

PRZESŁAWSKI, T. Funkcja czynnika psychicznego w konstrukcji czynu zabronionego i formach winy. Studia Iuridica. 2008, nr 48, pp. 219238. ISSN 0137-4346.

Ramy polityki bezpieczeństwa ruchu drogowego UE na lata 2021 - 2030 Kolejne kroki w kierunku realizacji „wizji zero“ [2019-06-19]. SWD (2019) 283 final.

REJMAN, G. Teorie i formy winy w prawie karnym. 1. wyd. Warszawa: Wydawnictwo Prawnicze, 1980. 263 p. ISBN 83-219-0059-3.

REJMAN, G. Wina w konstrukcji kodeksu karnego z 1997 roku. In: G. BAŁTRUSZAJTYS, ed. Prawo wczoraj i dziś: Studia dedykowane profesor Katarzynie Sójce-Zielińskiej. 1. wyd. Warszawa: Liber, 2000, pp. 261277. ISBN 83-7206-029-0.

Road Safety. In: Komisja Europejska [online]. 2019-03-13 [cit. 2020-0724]. Available at: https://ec.europa.eu/commission/news/road-safety-2019-mar-13_pl.

ROXIN, C. Bemerkungen zum Regreßverbot. In: H.-H. JESCHECK and T. VOGLER, Hrsg. Festschrift für Herbert Tröndle zum 70. Geburtstag am 24. August 1989 [online]. 1. Aufl. Berlin; New York: De Gruyter, 1989, pp. 177-200 [cit. 2020-07-24]. ISBN 978-3-11-089207-9. Available at: https://doi.org/10.1515/9783110892079-011.

ROXIN, C. Die Lehre von der objektiven Zurechnung. Chengchi Law Review. 1994, vol. 50, pp. 219-257. ISSN 1023-9820.

ROXIN, C. Pflichtwidrigkeit und Erfolg bei fahrlässigen Delikten. Zeitschrift für die gesamte Strafrechtswissenschaft [online]. 1962, Jg. 74, Nr. 3, pp. 411-444 [cit. 2020-07-24]. ISSN 1612-703X. Available at: https://doi.org/10.1515/zstw.1962.74.3.411.

ROXIN, C. Zur Problematik des Schuldstrafrechts. Zeitschrift für die gesamte Strafrechtswissenschaft [online]. 1984, Jg. 96, Nr. 3, pp.641660 [cit. 2020-07-24]. ISSN 1612-703X. Available at: https://doi.org/ 10.1515/zstw.1984.96.3.641. 
SPOTOWSKI, A. Funkcja niebezpieczeństwa w prawie karnym. 1. wyd. Warszawa: Państwowe Wydawnictwo Naukowe, 1990. 352 p. ISBN 83-01-09521-0.

STEFAŃSKI, R. A. Prawo o ruchu drogowym: Komentarz. 3. wyd. Warszawa: Wolters Kluwer, 2008. 1100 p. ISBN 978-83-7601-056-4.

STEFAŃSKI, R. A. Przestępstwa przeciwko bezpieczeństwu powszechnemu i w komunikacji: RozdziałXX i XXI Kodeksu karnego: Komentarz. 1. wyd. Warszawa: C. H. Beck, 2000. 692 p. ISBN 83-7110-239-9.

STEFAŃSKI, R. A. Przestępstwa przeciwko bezpieczeństwu w ruchu lądowym, wodnym lub powietrznym w projekcie kodeksu karnego. Problemy Praworządności. 1990, nr 8-9, p. 38 and following. ISSN 01378643.

STEFAŃSKI, R. A. Wykroczenia drogowe: Komentarz. 1. wyd. Kraków: Zakamycze, 2005. 664 p. ISBN 83-7444-215-8.

STEFAŃSKI, R. A. Wypadek w komunikacji jako przestępstwo w nowym kodeksie karnym. Prokuratura i Prawo. 1998, nr 10, pp. 47-70. ISSN 1233-2577.

Strafgesetzbuch [1998-11-13]. BGBl. I S. 3322, last changed by law on July 10, 2020 (BGBl. I S. 1648).

SZERER, M. W sprawie zamiaru ewentualnego. Państwo i Prawo. 1959, vol. 14, nr 3, p. 455 and following. ISSN 0031-0980.

Ścigali się ulicami miasta. Zginęły dwie osoby. Jest akt oskarżenia. In: Lwówecki.info [online]. 2019-10-16 [cit. 2020-07-24]. Available at: https://lwowecki.info/scigali-sie-ulicami-miasta-zginely-dwie-osoby-jest-akt-oskarzenia/.

TAYLOR, G. Concepts of Intention in German Criminal Law. Oxford Journal of Legal Studies [online]. 2004, vol. 24, no.1, pp. 99-127 [cit. 202007-24]. ISSN 1464-3820. Available at: https://doi.org/10.1093/ojls/ 24.1.99.

TIEDEMANN, K. Der Allgemeine Teil des Strafrechts im Lichte der europäischen Rechtsvergleichung. In: A. ESER, U. SCHITTENHELM and H. SCHUMANN, Hrsg. Festschrift für Theodor Lenckner zum 70. Geburtstag. 1. Aufl. München: C. H. Beck, 1998, pp. 411-434. ISBN 3-40643842-3. 
TOEPEL, F. Kausalität und Pflichtwidrigkeitszusammenhang beim fahrlässigen Erfolgsdelikt [online]. 1. Aufl. Berlin: Duncker \& Humblot, 1992. 244 p. [cit. 2020-07-24]. Strafrechtliche Abhandlungen: Neue Folge, Band 75. ISBN 978-3-428-47412-7. Available at: https://doi. org/10.3790/978-3-428-47412-7.

Ustawa z dnia 6 czerwca 1997 r. - Kodeks karny. Dziennik Ustaw 2019, item 1950, 2128; and Dziennik Ustaw 2020, item 568, 875, 1086.

WOLTER, J. Adäquanz- und Relevanztheorie: Zugleich ein Beitrag zur objektiven Erkennbarkeit beim Fahrlässigkeitsdelikt. Goltdammer's Archiv für Strafrecht. 1977, pp. 257-274. ISSN 0017-1956.

ZABŁOCKI, S. Przegląd orzecznictwa Sądu Najwyższego - Izba Karna. Palestra. 1999, nr 1-2, pp. 140-149. ISSN 0031-0344.

ZAWŁOCKI, R. Nieumyślność jako podstawa odpowiedzialności karnej w poszukiwaniu kompromisu. Monitor Prawniczy. 2008, vol. 16, nr 11, pp. 567-577. ISSN 1230-6509.

ZIPF, H. Kriminalpolitische Überlegungen zur Entkriminalisierung der fahrlässigen Körperverletzung. In: E. SCHLÜCHETER and K. LAUBENTHAL, Hrsg. Recht und Kriminalität: Festschrift für Friedrich-Wilhelm Krause zum 70. Geburtstag. 1. Aufl. Köln: Heymann, 1990, pp. 437447. ISBN 3-452-21890-2.

ZOLL, A. ed. Kodeks karny: Część szczególna: Komentarz: Tom II: Komentarz do art. 117 - 277 k.k. 2. wyd. Warszawa: Zakamycze, 2006. 1438 p. ISBN 83-7444-252-2.

ZOLL, A. Kilka uwag w związku z charakterem prawnym norm sankcjonujących wynikających z art. $178 \S 1$ k.k. In: A. MICHALSKA-WARIAS, I. NOWIKOWSKI and J. PIÓRKOWSKA-FLIEGER, eds. Teoretyczne i praktyczne problemy współczesnego prawa karnego: Księga jubileuszowa dedykowana Profesorowi Tadeuszowi Bojarskiemu. 1. wyd. Lublin: Wydawnictwo Uniwersytetu Marii Curie-Skłodowskiej, 2011, pp. 635-642. ISBN 978-83-7784-000-9.

ZOLL, A. Odpowiedzialność karna kierowcy za spowodowanie wypadku i nieudzielenie pomocy jego ofierze. Wojskowy Przegląd Prawniczy. 1969, nr 1, pp. 17-28. ISSN 0137-7272.

Renata Pawlik, Ph.D. 
Faculty of Law, Administration and International Relations Andrzej Frycz Modrzewski Krakow University Gustawa Herlinga-Grudzińskiego 1 30-705 Kraków Poland rpawlik@afm.edu.pl

(iD) https://orcid.org/0000-0003-3834-221X 